\title{
Analysis of trophic responses in lesioned brain: focus on basic fibroblast growth factor mechanisms
}

G. Chadi ${ }^{1}$ and K. Fuxe ${ }^{2}$

\section{Correspondence \\ G. Chadi \\ Departamento de Anatomia ICB, USP \\ Av. Prof. Lineu Prestes, 2415 05508-900 São Paulo, SP \\ Brasil \\ Fax: 55 (011) 813-0845 \\ E-mail:gerchadi@usp.br}

Presented at the 5 th International Symposium on Radioautography, São Paulo, SP, Brasil,

August 24-26, 1997.

Research supported by FAPESP

(No. 94/3858-3), CNPq

(No. 523005/94-6) and Sandoz

Foundation for Gerontological

Research (LA-94-2-08)

\author{
'Laboratório de Fatores Neurotróficos e Plasticidade Neuronal, \\ Departamento de Anatomia, Instituto de Ciências Biomédicas, \\ Universidade de São Paulo, São Paulo, SP, Brasil \\ 2Department of Neuroscience, Division of Cellular and Molecular \\ Neurochemistry, Karolinska Institute, Stockholm, Sweden
}

\section{Abstract}

The actions of fibroblast growth factors (FGFs), particularly the basic form (bFGF), have been described in a large number of cells and include mitogenicity, angiogenicity and wound repair. The present review discusses the presence of the bFGF protein and messenger RNA as well as the presence of the FGF receptor messenger RNA in the rodent brain by means of semiquantitative radioactive in situ hybridization in combination with immunohistochemistry. Chemical and mechanical injuries to the brain trigger a reduction in neurotransmitter synthesis and neuronal death which are accompanied by astroglial reaction. The altered synthesis of bFGF following brain lesions or stimulation was analyzed. Lesions of the central nervous system trigger bFGF gene expression by neurons and/or activated astrocytes, depending on the type of lesion and time post-manipulation. The changes in bFGF messenger RNA are frequently accompanied by a subsequent increase of bFGF immunoreactivity in astrocytes in the lesioned pathway. The reactive astrocytes and injured neurons synthesize increased amount of bFGF, which may act as a paracrine/autocrine factor, protecting neurons from death and also stimulating neuronal plasticity and tissue repair.

Intracellular and intercellular signals represented by protein growth factors are responsible for important cellular functions like mitosis, growth, chemotaxis and maintenance of cells in vitro and in vivo (1). Neurotrophic factors are substances with mitogenic activity on neurons and glial cells (2). Neurotrophic factors may maintain survival of neurons in vitro and protect embryonic and mature neurons from neurotoxicity in vitro and in vivo (3).
Key words

- Radioautography

- In situ hybridization

- Basic fibroblast growth

factor

- FGF receptor

- Astrocyte

- Image analysis

- Central nervous system

- Brain lesion
Received December 29, 1997

Accepted January 5, 1998
Since the discovery of nerve growth factor by Rita Levi Montalcini and Seymour Cohen in the 1950's as a soluble protein acting as a target-derived growth factor for sympathetic and sensory peripheral neurons, new neurotrophic factors and their mechanisms of action have been described (3-5). The large diversity of growth factors acting on neurons indicates their functional complexity (2). In general, the actions of neurotrophic molecules are related to the stage 
of development or maturity of the nervous tissue as well as to the stage of neuronal activation or lesion (6). Division, differentiation and maturation of neurons and glial cells are important actions of neurotrophic factors (7-9) during embryonic life. Furthermore, neurotrophic proteins expressed by the developmental central nervous system induce neuronal sprouting and outgrowth of fibers (10). Neurotrophic factors play a role also during adult life by inducing morphological and chemical changes in mature neurons (11-13).

Growth factors are grouped into families such as neurotrophins $(10,14-17)$, epidermal growth factor family $(18,19)$ and fibroblast growth factors (FGFs) (20). The protein and messenger RNA of neurotrophic molecules have been described in most areas of the central nervous system (21) and many of them show trophic properties towards neurons (22). Some features concerning the role of neurotrophic molecules are their actions on specific neuronal groups $(12,23)$ or neurons from different regions of the central nervous system (24). They can also modulate different intracellular messenger systems $(25,26)$ and the expression of immediate or secondary response genes $(27,28)$. Furthermore, neurotrophic factors promote single or multifunctional actions on neurons and participate in intercellular communication events, which may lead to a modulation of their final effects in a neuronal cell population $(26,29)$.

Nerve growth factor was the first described and to date is the best understood member of the neurotrophins. Nerve growth factor and the other members of its family, i.e., brain-derived neurotrophic factor and neurotrophin-3, have been found in the central nervous system (3,30-32). Insulin-like growth factor, transforming growth factor, epidermal growth factor and glial-derived neurotrophic factor are also examples of neurotrophic factors present in the central nervous system which show neurotrophic activity towards neurons $(1,12,18,21,22,25$, 30,33,34).

Trowell and collaborators (35) in the 1930 's described the presence of high mitogenic activity of pituitary and brain extracts on fibroblasts. Purification procedures soon revealed the presence of two compounds, an acid one and a basic one, sharing $60 \%$ homology (36-38) which were called acidic (aFGF) and basic (bFGF) fibroblast growth factors, respectively. These molecules exert their effects on a large spectrum of cells, comprising fibroblasts and endothelial cells (39) and on nerve tissue including neurons and glial cells (40).

Immunohistochemistry and in situ hybridization demonstrated the presence of aFGF mainly located in specific nerve cell groups of the central nervous system, like peripheral somatic motor neurons (41). bFGF has also been described in many brain regions (42-45).

The spectrum of biological actions of bFGF includes mitogenicity and cell proliferation, differentiation, maintenance, migration and repair (46). In view of the widespread distribution and multifunctional actions of bFGF, many reports regarding the role of this neurotrophic molecule in the central nervous system have been published in the last eight years.

It is known that bFGF is able to stimulate the proliferation of neuronal and glial progenitors isolated from adult rat brain (47) as well as to induce survival and differentiation of transplanted adult neuronal progenitor cells (48). bFGF has been shown to enhance neurite outgrowth in cultured rat spinal cord and hippocampal neurons $(49,50)$, which can be blocked by heparitinase or tyrosine inhibitors (49). Furthermore, bFGF can inhibit apoptotic cell death of cultured cortical neurons from embryonic rats induced by $\mathrm{Ca}^{2+}$ ionophores (51).

Evidence has indicated that bFGF plays a role in the nigrostriatal dopamine system. bFGF has been demonstrated to be a potent 
trophic agent for embryonic, neonate and adult dopamine cells in vitro and in vivo $(19,52,53)$, while aFGF requires heparin for its effects on fetal midbrain neurons (19). Cells genetically modified to produce bFGF have potent growth-promoting effects and function on fetal dopamine neurons implanted into rats with experimental parkinsonism (54). Although bFGF immunoreactivity is not modified in dopaminergic neurons of the substantia nigra during normal aging in humans, it is reduced in this cell group of patients with Parkinson's disease (55), which suggests its role in neurodegenerative disorders.

Mappings of the bFGF protein and messenger RNA and its receptor messenger RNA as well as its altered synthesis following experimental brain lesions have been analyzed by immunohistochemistry and in situ hybridization radioautography in order to evaluate the role of bFGF in the adult brain. Immunohistochemistry and in situ hybridization are frequently employed in these analyses since they can be easily measured and permit evaluation of the responses at the cell level.

bFGFimmunohistochemistry employing a bFGF polyclonal antibody shows bFGF immunoreactivity in the cytoplasm of neurons and in the nuclei of glial cells (42$44,56-59)$ widely distributed in the developing and mature rodent central nervous system (60). However, the use of monoclonal bFGF antiserum has revealed the protein in the nuclei of glial cells throughout the forebrain and the midbrain as well as in the nuclei of some neuronal cells like those of layer II of retrosplenial granular cortex, the CA2 region of the hippocampus, the indusium griseum and the fasciola cinerea $(45,61)$.

bFGF messenger RNA has been mapped in the embryonic and adult brain (58,61-63). In the normal adult rat, hybridization of ${ }^{35} \mathrm{~S}$ labelled bFGF cRNA densely labelled neurons in few discrete areas, including the tenia tecta, indusium griseum, and hippo- campal stratum pyramidale of regions CA2, as illustrated in Figure 1A,B. Diffuse distribution of radioautographic labelling throughout the forebrain is suggestive of localization in glial cells (63).

The FGFs function through high affinity plasma membrane receptors with tyrosine kinase activity $(49,64,65)$. Different subtypes of FGF receptors have been described in the central nervous system $(66,67)$, explaining the multifunctional action of bFGF (67).

A large number of nerve cell populations in the adult rat brain were found to express FGF receptor messenger RNA using a rat FGF receptor cRNA probe which showed moderate labelling in the dopamine cell bodies of the substantia nigra and ventral tegmental area and other aminergic nerve cell groups in the brainstem $(43,68)$. Strong labelling was detected over pyramidal cells in all subregions of the cornus Amon, particularly in the CA2 subregion, as well as in the dentate gyrus $(43,68)$. Figure $1 \mathrm{~F}$ shows high expression of the FGF receptor signal in the pyramidal cell layer of the hippocampal formation and in the dentate gyrus in a coronal section of the adult mouse brain by means of in situ hybridization radioautography using a riboprobe for the full length (flg) of the FGF receptor. Subtypes of the FGF receptor have just started to be mapped and FGF receptor type 1 messenger RNA was described in the embryonic and adult rat central nervous system (62).

bFGF is synthesized as different molecular mass isoforms which lack the signal peptide sequence for secretion. The different forms are translated via alternate initiation codons. High molecular weight forms of the bFGF initiate at CUG codons, whereas the 18-kDa form initiates at an AUG codon (69). The low $18-\mathrm{kDa}$ isoform is mainly localized in the cytosol and the high molecular mass isoforms (21-24 $\mathrm{kDa}$ ) possess a signal sequence directing their nuclear translocation (70). It might be possible that the cytosolic and nuclear localization of bFGF isoforms is 

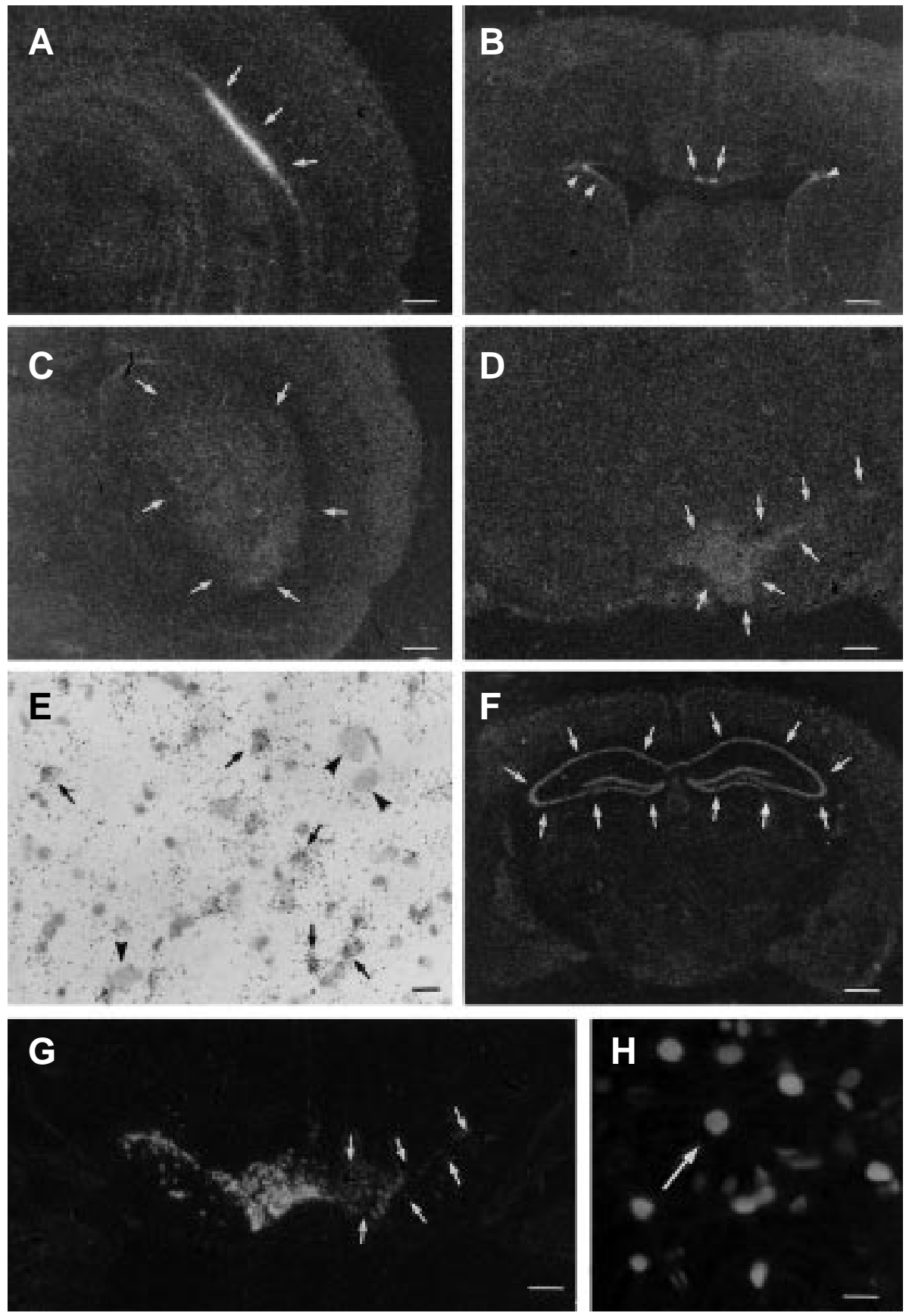

Figure 1 - Photomicrographs of film autoradiograms (A-D,G) and bright-field microscopy (E) of coronal sections of rat brain showing in situ hybridization of bFGF mRNA (A-D) and tyrosine hydroxylase mRNA (G) after unilateral nigral injection of saline (A-B) or 6-hydroxydopamine (6-OHDA) (C,D,G). The bFGF mRNA signal is seen in the CA2 region of the hippocampal formation (arrows in A) as well as in the indusium griseum (arrows) and subventricular regions (arrowheads) (B). The ipsilateral caudate putamen nucleus $(C)$ and the ipsilateral pars compacta of the substantia nigra and ventral tegmental area (D) show a strong increase in bFGF mRNA $24 \mathrm{~h}$ and 7 days after the neurotoxin injection, respectively. After film emulsion dipping of the hybridized section, bright-field microscopy of the bFGF mRNA signal shows silver grains over cresyl violet-counterstained small putative glial nuclei (arrows) in the sections from the pars compacta $(E)$ of a 6 -hydroxydopamine ( 7 days)-injected rat. Clusters of silver grains are not found over putative neuronal profiles (arrowheads) in the above cited regions (E). Disappearance of tyrosine hydroxylase mRNA is observed in the region of dopaminergic lesions (arrows in $\mathrm{G})$. Double immunofluorescence shows bFGF immunoreactivity in the nuclei of glial fibrillary acidic protein-immunoreactive astrocytes $(\mathrm{H})$. Figure $\mathrm{F}$ illustrates the presence of the FGF receptor (flg) mRNA signal in the film autoradiograms localized in the hippocampal formation of mouse brain (arrows). Scale bars $=1000 \mu \mathrm{m}(\mathrm{A}-\mathrm{D}, \mathrm{F}, \mathrm{G}), 50 \mu \mathrm{m}(\mathrm{E}), 25 \mu \mathrm{m}(\mathrm{H})$. 
related to different functional properties of the molecule (69). Nuclear bFGF has been considered to be involved in the regulation of nuclear events such as gene expression and transcription $(65,71)$. Furthermore, the synthesis of bFGF proteins could play a role in cell function by modifying the intracellular signaling pathway, by modulating both adenylate cyclase activity and the regulatory G-proteins and also by interfering with cAMP to regulate cell proliferation (72). The different molecular weight forms of bFGF also show functional differences on FGF receptor function. It was reported that the 22.5$\mathrm{kDa}$ isoform of the bFGF acts by increasing FGF receptor type 1 messenger RNA stability, thus enhancing cell responses to exogenous bFGF (73).

It has been postulated that intracellular bFGF is released by alternative mechanisms (18). The extracellular matrix represents a natural reservoir for various heparin-binding growth factors (66). bFGF interacts with heparin-like polysaccharides and the heparan sulfate proteoglycans of the extracellular matrix may also be involved in the presentation of bFGF to its cell surface high affinity receptor located in the neuroglia and neurons, even though this is not essential for high affinity binding to occur $(74,75)$. This interaction may facilitate the signal transduction pathway of the molecule (76), thus providing a regulatory mechanism for its paracrine biological activity $(77,78)$. After binding to heparan sulfate proteoglycans or to FGF tyrosine kinase receptors, bFGF is internalized by different pathways (79).

Heparin-binding growth factors, i.e. bFGF, are thought to play a role in the processes of tissue homeostasis, regeneration or repair following injury. These factors are active upon release from neighboring inflammatory or lesioned cells, as well as upon release from heparan sulfate associated with the extracellular matrix (80). It is known that the cells of a mechanically injured tissue release biologically active substances and that the conditioned medium from injured cultured cells is highly mitogenic probably due to the presence of growth factors (18). Since bFGF has been reported to induce its own gene expression (71), once released it might be responsible for the increase in $b F G F$ messenger RNA in the neighborhood of the lesioned cell. Sublethal injury triggers the increases in the transcriptional activation of the bFGF gene which may be related to the recovery from cell injury (81).

Regulation of the bFGF protein and messenger RNA at the cellular level following experimental lesions applied to the rat brain has been analyzed in order to evaluate the trophic responses of the adult central nervous system. 6-Hydroxydopamine is known to induce lesion in the ascending dopamine pathway and to promote experimental parkinsonism in rats (61). Figure $1 \mathrm{G}$ shows a radioautogram of in situ hybridization of the tyrosine hydroxylase messenger RNA to demonstrate the disappearance of the signal in the pars compacta of the substantia nigra and ventral tegmental area following injury to dopamine cells of a rat that received a stereotaxic nigral injection of 6-hydroxydopamine and was sacrificed 7 days later.

Chadi and collaborators (61) demonstrated by means of in situ hybridization a sustained (from $4 \mathrm{~h}$ to 2 weeks) and strong (300-400\% of control, at the peak intervals) increase of bFGF messenger RNA in the pars compacta of the substantia nigra and the ventral tegmental area ipsilateral to the lesion. A short-lasting increase of bFGF RNA was observed in the ipsilateral pars reticulata of the substantia nigra (from $4 \mathrm{~h}$ to $24 \mathrm{~h}$, $300 \%$ of control) and neostriatum $(24 \mathrm{~h}$, $180 \%$ of control) as well as in the ipsilateral and contralateral hippocampus and neocortex (by 4 h, 200\% of control). Figure 1C,D illustrates the expression of bFGF messenger RNA in the lesioned neostriatum and lesioned pars compacta of the substantia nigra and ventral tegmental area, $24 \mathrm{~h}$ and 7 days after a unilateral nigral injection of 6- 
Figure 2 - Effects of a nigral 6hydroxydopamine (6-OHDA) injection on the basic fibroblast growth factor (bFGF) mRNA levels in the ipsilateral pars compacta of the substantia nigra (SNC), ventral tegmental area (VTA) and caudate putamen (CP) nucleus 7 days and $24 \mathrm{~h}$ after the injection, respectively, using in situ hybridization procedures combined with image analysis. The numbers represent the percent values of the specific optical density values obtained in the respective regions of control saline-injected animals $(\mathrm{N}=3-6)$. ${ }^{*} \mathrm{P}<0.05$ compared to respective control (Mann-Whitney U-test).

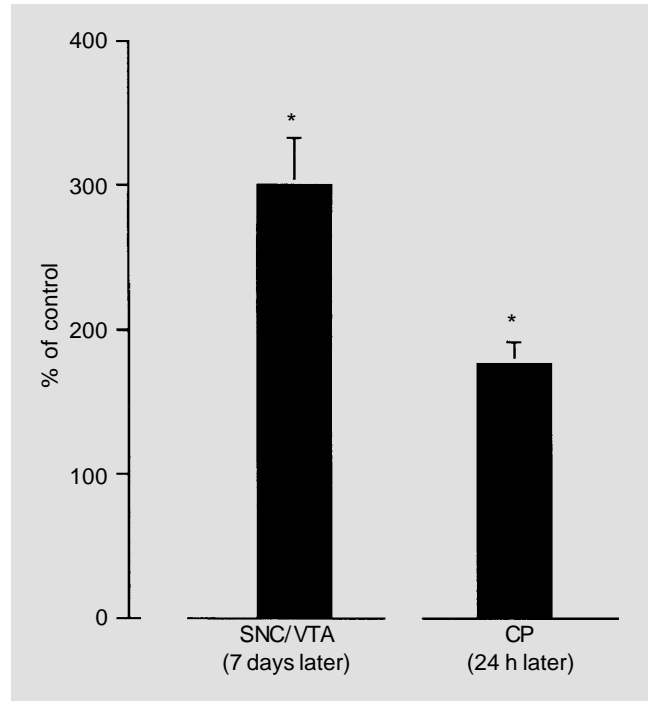

hydroxydopamine. The degree of the changes in the bFGF messenger RNA signal in the hybridized sections was quantitated by means of image analysis and the results obtained for the pars compacta of the substantia nigra/ ventral tegmental area and for the neostriatum are shown in Figure 2. Bright-field microscopy demonstrated an increased number of putative glial cells expressing the bFGF messenger RNA signal (Figure 1E). bFGF immunohistochemistry revealed that as early as $2 \mathrm{~h}$ after drug injection, the density of glial bFGF immunoreactive profiles was increased in the pars compacta of the substantia nigra and the ventral tegmental area. bFGF immunoreactivity was increased in the nuclei of astrocytes only within the ipsilateral substantia nigra and ventral tegmental area at 72 $\mathrm{h}$, and 1 week after the injection of 6-hydroxydopamine (61). Figure $1 \mathrm{H}$ shows a double immunofluorescence for the simultaneous detection of the bFGF and glial fibrillary acidic protein (a marker for astrocytes) immunoreactivity in the pars compacta of the substantia nigra of a 7-day-6-hydroxydopamine-lesioned rat. Reactive astrocytes show hypertrophied cytoplasm and processes and increased bFGF immunoreactivity.

Mechanical lesions of the central nervous system also trigger increases of bFGF and its messenger RNA in reactive astro- cytes mostly localized close to the wound. The upregulated synthesis of the astroglial bFGF, as seen by the increase in bFGF messenger RNA and protein after mechanical lesion, was described following implantation of a microdialysis probe into the rat hippocampus (59).

The trophic responses of bFGF have been also evaluated in the forebrain of the rat submitted to exotoxicity $(58,82)$. Radioactive in situ hybridization revealed a fast (6 h), strong (300-400\% of control) and widespread increase of bFGF messenger RNA after kainate-induced epileptic seizures (58). Transcript analysis at the cellular level by nonradioactive in situhybridization revealed a marked increase of messenger RNA in the nuclei of astrocytes in several forebrain regions. These changes were accompanied by an enhancement of bFGF immunoreactivity in the nuclei of reactive astrocytes (58).

The expression of bFGF messenger RNA is not only triggered by strong lesions like the one induced by 6-hydroxydopamine on dopamine cells (61) but is highly enhanced following the acute stage of focally evoked convulsive seizures (83) and cerebral contusion (84). Brief exposure to hypoxia also induces increases in bFGF messenger RNA and protein which are considered to protect rat cortical neurons from prolonged hypoxic stress (85). It is interesting that perinatal asphyxia during birth triggers increases in bFGF gene expression that are accompanied by an increased number of dopamine nerve cell bodies in the mesencephalon of the rat (86). Hypoxia of the mature nervous tissue also increases bFGF messenger RNA (87).

Bilateral recurrent seizure activity induced by a focal stainless-steel wire in the hippocampal hilus increases bFGF messenger RNA in astrocytes throughout the forebrain and also in neurons of the dentate gyrus and olfactory cortex (63). Furthermore, it was also shown that limbic motor seizures produced by kainate injection trigger a fast elevation of bFGF gene expression 
in rat hippocampus and striatum. In the hippocampus, a fast increase of bFGF messenger RNA was localized in the neurons of the dentate gyrus and the CA1 layer, whereas the messenger RNA levels remained unchanged in astrocytes. It is also possible that the neuronal activity may regulate the bFGF gene expression in an autocrine and intracrine fashion at an early time, whereas delayed expression is related to paracrine trophic actions taking place in the activated astrocytes following neuronal injury (82). It is possible that the expression of bFGF messenger RNA in neurons is related to the degree of neuronal activation since enhanced noradrenergic tone evoked by the lipophilic beta-adrenergic receptor agonist clenbuterol elicited only an increase in the levels of glial bFGF messenger RNA as seen in the cerebral cortex and hippocampus (32).

The increased synthesis of bFGF following lesions of the central nervous system is accompanied by an increased gene expression of the FGF receptor as seen by in situ hybridization technique (88).

Expression of $c$-fos messenger RNA after cortical ablation in the rat brain is modulated by bFGF and the NMDA receptor is also involved in the expression of this immediate early gene (89). Furthermore, bFGF may maintain the homeostasis of the intracellular $\mathrm{Ca}^{2+}$ concentration and thus protect against glutamate-induced neurotoxicity (64).

It is well known that the interactions between glial cells and neurons are important for neuronal trophism in the central nervous system $(8,34,52,90)$; however, the neurotrophic factor-mediated paracrine trophic actions of glial cells on neurons are only now beginning to be investigated.

Astroglial cells express neurotrophic and/ or neurite growth-promoting factors that are regulated during development and/or after central nervous system lesions and exert protective or regenerative effects on neurons following lesions $(8,91)$.

The glia-promoted neuronal trophism via

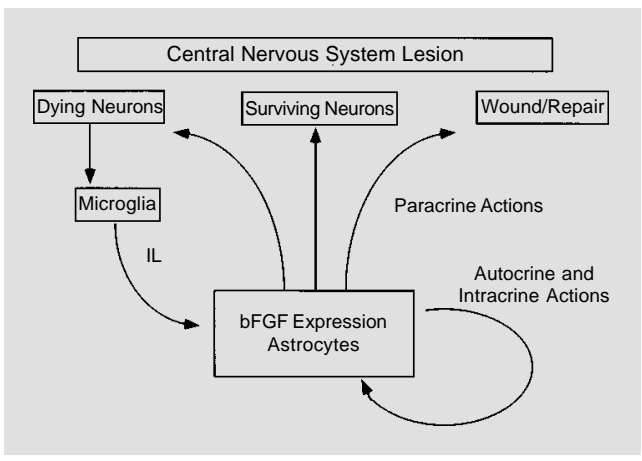

trophic factors has been described in several neurotransmitter systems. It is known that bFGF reduces the number of dopamine cells undergoing apoptotic cell death and also alters motor function and improves the survival of fetal ventral mesencephalic grafts, actions that depend on the proliferation of glial cells since they were blocked by cytosine arabinoside $(34,92)$. Furthermore, bFGF can influence the survival of cholinergic neurons by stimulating and increasing glia, which may produce factor(s) that are necessary for cholinergic neuron survival (93). It was speculated that trophic responses to multiple growth factors may compensate for the endogenous deficiency in glial factors and/or the presence of glial inhibitory factors in the central nervous system (33).

The interactions between glial cells may modulate the paracrine trophic actions of these cells to neurons. Interleukins released by reactive microglia following brain injury are capable of stimulating the synthesis of neurotrophic factors by astrocytes (90). In fact, it was demonstrated that interleukin-1 beta increases bFGF messenger RNA expression in adult rat brain and organotypic hippocampal cultures (94). Figure 3 illustrates some possible autocrine, intracrine and paracrine mechanisms of the upregulated glial bFGF following a central nervous system lesion.

Although regeneration of injured neurons does not occur after trauma in the central nervous system, functional recovery is commonly observed. The increased trophic
Figure 3 - Schematic illustration of the possible action of glial basic fibroblast growth factor (bFGF) which is upregulated following a central nervous system lesion. Injured neurons trigger the secretion of interleukins (IL) by activated microglia which stimulate astrocytes to become reactive. The synthesis of bFGF is then upregulated in the reactive astrocytes. bFGF prolongs the activation of astrocytes via autocrine and intracrine actions and may help maintain lesioned neurons as well as promote repair via a paracrine action. 
activity in the injured central nervous system and the properties of neurotrophic factors in neuronal growth and maintenance suggest that these polypeptides are probably involved in recovery of function by stimulating neurite outgrowth in the surviving neurons or in the related/neighbor pathway, needed for reorganization of the injured nerve tissue. Neurotrophic factors also stimulate neurotransmitter synthesis probably to compen- sate for the reduced neuronal actions, to sustain survival of injured neurons and to stimulate revascularization and glial responses to injury (31).

\section{Acknowledgment}

We thank Ms. Maria S.P. Abel for technical assistance and Mr. Andrés E.P. Ruiz for the photography work.

\section{References}

1. Loughlin SE \& Fallon JH (1993). Neurotrophic Factors. Academic Press, Inc., San Diego.

2. Hefti F, Denton TL, Knusel B \& Lapchak PA (1993). Neurotrophic factors: what are they and what are they doing? In: Loughlin SE \& Fallon JH (Editors), Neurotrophic Factors. Academic Press, Inc., San Diego, 25-49.

3. Thoenen H \& Barde YA (1980). Physiology of nerve growth factor. Physiological Reviews, 60: 1284-1335.

4. Levi-Montalcini R \& Hamburger V (1953). A diffusible agent of mouse sarcoma, producing hyperplasia of sympathetic ganglia hyperneurotization of viscera in the chick embryo. Journal of Experimental Zoology, 123: 233-287.

5. Cohen $S$, Levi-Montalcini $R$ \& Hamburger $V$ (1954). A nerve growth-stimulating factor isolated from snake venom. Proceedings of the National Academy of Sciences, USA, 40: 1014-1018.

6. Hefti F, Hartikka J \& Knusel B (1989). Function of neurotrophic factors in the adult and aging brain and their possible use in the treatment of neurodegenerative diseases. Neurobiology of Aging, 10: 515-533.

7. Barotte C, Eclancher F, Ebel A Labourdette G, Sensenbrenner M \& Will B (1989). Effects of basic fibroblast growth factor (bFGF) on choline acetyltransferase activity and astroglial reaction in adult rats after partial fimbria transection. Neuroscience Letters, 101: 197-202.

8. Baumann N, Baron-Van Evercooren A Jacque C \& Zalc B (1993). Glial biology and disorders. Current Opinion in Neurology and Neurosurgery, 6: 27-33.

9. Noble M \& Wolswijk G (1992). Development and regeneration in the O-2A lineage. Journal of Neuroimmunology, 40: 287-294.
10. Thoenen $H$, Bandtlow $\mathrm{C}$ \& Heumann $\mathrm{R}$ (1987). The physiological function of nerve growth factor in the central nervous system: Comparison with the periphery. Reviews of Physiology, Biochemistry and Pharmacology, 109: 145-178.

11. Kamegai $M$, Niijima $K$, Kunishita $T$, Nishizawa M, Ogawa M, Araki M, Ueki A, Konishi Y \& Tabira T (1990). Interleukin-3 as a trophic factor for central cholinergic neurons in vitro and in vivo. Neuron, 2 : 429-436.

12. Knusel B, Michel PP, Schwaber JS \& Hefti $F$ (1990). Selective and nonselective stimulation of central cholinergic and dopaminergic development in vitro by nerve growth factor, basic fibroblast growth factor, epidermal growth factor, insulin and the insulin-like growth factors I and II. Journal of Neuroscience, 10: 558-570.

13. Korr H, Siewert E, Bertram C, Labourdette G \& Sensenbrenner M (1992). Autoradiographic studies of rat astroglial cell proliferation in vitro with and without treatment with basic fibroblast growth factor. Cell Proliferation, 25: 605-622.

14. Barde YA, Edgar D \& Thoenen H (1982). Purification of a new neurotrophic factor from mammalian brain. EMBO Journal, 1: 549-553.

15. Ernfors $\mathrm{P}$, Lonnerberg $\mathrm{P}$, Ayer LC \& Persson H (1990). Developmental and regional expression of basic fibroblast growth factor mRNA in the rat central nervous system. Journal of Neuroscience Research, 27: 10-15.

16. Hallbook F, Ibanez CF \& Persson H (1991). Evolutionary study of nerve growth factor family reveals a new member abundantly expressed in Xenopus ovary. Neuron, 6: 845-858.
17. Berkemeier LR, Winslow JW, Kaplan DR, Nikolics K, Goeddel DV \& Rosenthal A (1991). Neurotrophin-5: A novel neurotrophic factor that activates trk and trkB. Neuron, 7: 857-866.

18. Crowley ST, Ray CJ, Nawaz D, Majack RA \& Horwitz LD (1995). Multiple growth factors are released from mechanically injured vascular smooth muscle cells. American Journal of Physiology, 269: 1641-1647.

19. Mena MA, Casarejos MJ, Gimenez GG \& Garcia DYJ (1995). Fibroblast growth factors: structure-activity on dopamine neurons in vitro. Journal of Neural Transmission, Parkinsons Disease Dementia Section, 9: 1-14.

20. Baird A \& Klagsbrun M (1991). The fibroblast growth factor family: An overview. In: Baird A \& Klagsbrun M (Editors), The Fibroblast Growth Factor Family. Annals of the New York Academy of Sciences, New York, xi.

21. Fallon JH, Annis CM, Gentry LE, Twarzik DR \& Loughlin SE (1990). Localization of cells containing transforming growth factor alfa precursor immunoreactivity in the basal ganglia of the adult rat brain. Growth Factors, 2: 241-250.

22. Nakao $\mathrm{N}$, Odin $\mathrm{P}$, Lindvall $\mathrm{O}$ \& Brundin $\mathrm{P}$ (1996). Differential trophic effects of basic fibroblast growth factor, insulin-like growth factor-1, and neurotrophin-3 on striatal neurons in culture. Experimental Neurology, 138: 144-157.

23. Roher H (1990). The role of growth factors in the control of neurogenesis. European Journal of Neuroscience, 2: 10051015.

24. Walicke PA (1988). Basic and acidic fibroblast growth factors have trophic effects on neurons from multiple CNS regions. Journal of Neuroscience, 8: 2618-2627. 
25. Krupinski J, Rajaram R, Lakonishok M, Benovic JL \& Cerione RA (1988). Insulindependent phosphorylation of GTP-binding proteins in phospholipid vesicles. Journal of Biological Chemistry, 263: 1233312341.

26. Hendry IA \& Crouch MF (1993). Synergy, retrograde transport and cell death. In: Loughlin SE \& Fallon JH (Editors), Neurotrophic Factors. Academic Press, Inc., San Diego, 51-87.

27. Sharp FR, Gonzalez MF, Hizanaga K, Mobley WC \& Sagar SM (1989). Induction of the c-fos gene product in the rat forebrain following cortical lesions and NGF injections. Neuroscience Letters, 100: 117-122.

28. Gizang-Ginsberg E \& Ziff EB (1990). Nerve growth factor regulates tyrosine hydroxylase gene transcription through a nucleoprotein complex that contain c-fos. Genes and Development, 4: 477-491.

29. Sporn MB \& Roberts AB (1988). Peptide growth factors are multifunctional. Nature, 332: 217-219.

30. Fallon JH \& Loughlin SE (1993). Functional implications of the anatomical localization of neurotrophic factors. In: Loughlin SE \& Fallon JH (Editors), Neurotrophic Factors. Academic Press, Inc., San Diego, 1-24.

31. Mocchetti I \& Wrathall JR (1995). Neurotrophic factors in central nervous system trauma. Journal of Neurotrauma, 12: 853-870.

32. Hayes VY, Isackson PJ, Fabrazzo M, Follesa P \& Mocchetti I (1995). Induction of nerve growth factor and basic fibroblast growth factor mRNA following clenbuterol: contrasting anatomical and cellular localization. Experimental Neurology, 132: 33-41.

33. Faber EA, Solomon A, Abraham JA, Marikovsky M \& Schwartz M (1996). Involvement of wound-associated factors in rat brain astrocyte migratory response to axonal injury: in vitro simulation. Journal of Clinical Investigation, 97: 162-171.

34. Zawada WM, Kirschman DL, Cohen JJ, Heidenreich KA \& Freed CR (1996). Growth factors rescue embryonic dopamine neurons from programmed cell death. Experimental Neurology, 140: 6067.

35. Trowell OA, Chir B \& Willmer EN (1939). Growth of tissues in vitro. IV. The effects of some tissue extracts on the growth of periosteal fibroblasts. Journal of Experimental Biology, 16: 60-70.
36. Gospodarowicz D (1987). Isolation and characterization of acidic and basic fibroblast growth factor. Methods in Enzymology, 147: 106-119.

37. Gospodarowicz D, Cheng J, Lui G-M, Baird A \& Böhlen P (1984). Isolation of brain fibroblast growth factor by heparinSepharose affinity chromatography: identity with pituitary fibroblast growth factor. Proceedings of the National Academy of Sciences, USA, 81: 6963-6967.

38. Lobb RR, Harper JW \& Fett JW (1986). Purification of heparin-binding growth factors. Analytical Biochemistry, 154: 1-14.

39. Gospodarowicz D, Neufeld G \& Schweigerer L (1987). Fibroblast growth factor: structural and biological properties. Journal of Cellular Physiology, 5 (Suppl): 15-26.

40. Lamb TM \& Harland RM (1995). Fibroblast growth factor is a direct neural inducer, which combined with noggin generates anterior-posterior neural pattern. Development, 121: 3627-3636.

41. Kuzis K, Reed S, Cherry NJ, Woodward WR \& Eckenstein FP (1995). Developmental time course of acidic and basic fibroblast growth factors' expression in distinct cellular populations of the rat central nervous system. Journal of Comparative Neurology, 358: 142-153.

42. Chadi G, Rosen L, Cintra A, Tinner B, Zoli M, Pettersson RF \& Fuxe K (1993). Corticosterone increases FGF-2 (bFGF) immunoreactivity in the substantia nigra of the rat. Neuroreport, 4: 783-786.

43. Fuxe K, Chadi G, Agnati LF, Tinner B, Rosén L, Janson AM, Møller A, Cintra A, Cao Y, Goldstein M, Lindahl U, David G, Ögren S, Toffano G, Baird A \& Pettersson RF (1993). Fibroblast growth factor-2, ganglioside GM1 and the trophic regulation of the basal ganglia. Focus on the nigrostriatal dopamine neurons. In: Fuxe K, Agnati LF, Bjelke B \& Ottoson D (Editors), Trophic Regulation of the Basal Ganglia. Focus on Dopamine Neurons. Pergamon Press, Oxford, Stockholm, Sweden, 1-41.

44. Matsuda S, Okumura N, Yoshimura H, Koyama Y \& Sakanaka M (1992). Basic fibroblast growth factor-like immunoreactivity in Purkinje cells of the rat cerebellum. Neuroscience, 50: 99-106.

45. Woodward WR, Nishi R, Meshul CK, Williams TE, Coulombe $M$ \& Eckenstein FP (1992). Nuclear and cytoplasmic localization of basic fibroblast growth factor in astrocytes and CA2 hippocampal neurons. Journal of Neuroscience, 12: 142-152.
46. Kilpatrick TJ \& Bartlett PF (1995). Cloned multipotential precursors from the mouse cerebrum require FGF-2, whereas glial restricted precursors are stimulated with either FGF-2 or EGF. Journal of Neuroscience, 15: 120-127.

47. Temple S \& Qian X (1995). bFGF, neurotrophins, and the control or cortical neurogenesis. Neuron, 15: 249-252.

48. Gage FH, Coates PW, Palmer TD, Kuhn HG, Fisher LJ, Suhonen JO, Peterson DA, Suhr ST \& Ray J (1995). Survival and differentiation of adult neuronal progenitor cells transplanted to the adult brain. Proceedings of the National Academy of Sciences, USA, 92: 11879-11883.

49. Aoyagi A, Nishikawa $K$, Saito $H$ \& Abe $K$ (1994). Characterization of basic fibroblast growth factor-mediated acceleration of axonal branching in cultured rat hippocampal neurons. Brain Research, 661: 117-126.

50. Iwasaki Y, Shiojima T, Ikeda K, Tagaya N, Kobayashi T \& Kinoshita M (1995). Acidic and basic fibroblast growth factors enhance neurite outgrowth in cultured rat spinal cord neurons. Neurological Research, 17: 70-72.

51. Takei N, Ogaki H \& Endo $Y$ (1995). Basic fibroblast growth factor inhibited $\mathrm{Ca}^{2+}$ ionophore-induced apoptotic cell death of cultured cortical neurons from embryonic rats. Neuroscience Letters, 192: 124-126.

52. Chadi G, Moller A, Rosen L, Janson AM, Agnati LA, Goldstein M, Ogren SO, Pettersson RF \& Fuxe K (1993). Protective actions of human recombinant basic fibroblast growth factor on MPTP. lesioned nigrostriatal dopamine neurons after intraventricular infusion. Experimental Brain Research, 97: 145-158.

53. Kirschner PB, Henshaw R, Weise J, Trubetskoy V, Finklestein S, Schulz JB \& Beal MF (1995). Basic fibroblast growth factor protects against excitotoxicity and chemical hypoxia in both neonatal and adult rats. Journal of Cerebral Blood Flow and Metabolism, 15: 619-623.

54. Takayama H, Ray J, Raymon HK, Baird A, Hogg J, Fisher LJ \& Gage FH (1995). Basic fibroblast growth factor increases dopaminergic graft survival and function in a rat model of Parkinson's disease. Nature Medicine, 1: 53-58.

55. Tooyama I, McGeer EG, Kawamata T Kimura H \& McGeer PL (1994). Retention of basic fibroblast growth factor immunoreactivity in dopaminergic neurons of the substantia nigra during normal aging in humans contrasts with loss in Parkinson's disease. Brain Research, 656: 165-168. 
56. Matsuyama A, Iwata $\mathrm{H}$, Okumura $\mathrm{N}$, Yoshida S, Imaizumi K, Lee Y, Shiraishi S \& Shiosaka $S$ (1992). Localization of basic fibroblast growth factor-like immunoreactivity in the rat brain. Brain Research, 587: 49-65.

57. Chadi G, Tinner B, Agnati LF \& Fuxe K (1993). Basic fibroblast growth factor (bFGF, FGF-2) immunoreactivity exists in the noradrenaline, adrenaline and 5-HT nerve cells of the rat brain. Neuroscience Letters, 160: 171-176.

58. Humpel C, Lippoldt A, Chadi G, Ganten D, Olson L \& Fuxe K (1993). Fast and widespread increase of basic fibroblast growth factor messenger RNA and protein in the forebrain after kainate-induced seizures. Neuroscience, 57: 913-922.

59. Humpel C, Chadi G, Lippoldt A, Ganten D, Fuxe K \& Olson L (1994). Increase of basic fibroblast growth factor (bFGF, FGF-2) messenger RNA and protein following implantation of a microdialysis probe into rat hippocampus. Experimental Brain Research, 98: 229-237.

60. Eckenstein FP, Kuzis K, Nishi R, Woodward WR, Meshul C, Sherman L \& Ciment G (1994). Cellular distribution, subcellular localization and possible functions of basic and acidic fibroblast growth factors. Biochemical Pharmacology, 47: 103-110.

61. Chadi G, Cao Y, Pettersson RF \& Fuxe K (1994). Temporal and spatial increase of astroglial basic fibroblast growth factor synthesis after 6-hydroxydopamine-induced degeneration of the nigrostriatal dopamine neurons. Neuroscience, 61: 891-910.

62. Grothe $C$ \& Meisinger $C$ (1995). Fibroblast growth factor (FGF)-2 sense and antisense mRNA and FGF receptor type 1 mRNA are present in the embryonic and adult rat nervous system: specific detection by nuclease protection assay. Neuroscience Letters, 197: 175-178.

63. Gall CM, Berschauer R \& Isackson PJ (1994). Seizures increase basic fibroblast growth factor mRNA in adult rat forebrain neurons and glia. Brain Research, Molecular Brain Research, 21: 190-205.

64. Mattson MP, Lovell MA, Furukawa K \& Markesbery WR (1995). Neurotrophic factors attenuate glutamate-induced accumulation of peroxides, elevation of intracellular $\mathrm{Ca}^{2+}$ concentration, and neurotoxicity and increase antioxidant enzyme activities in hippocampal neurons. Journal of Neurochemistry, 65: 1740-1751.
65. Hawker JJ \& Granger HJ (1994). Tyrosine kinase inhibitors impair fibroblast growth factor signaling in coronary endothelial cells. American Journal of Physiology, 266: 107-120.

66. Soulet L, Chevet E, Lemaitre G, Blanquaert $F$, Meddahi A \& Barritault D (1994). FGFs and their receptors, in vitro and in vivo studies: new FGF receptor in the brain, FGF-1 in muscle, and the use of functional analogues of low-affinity heparin-binding growth factor receptors in tissue repair. Molecular Reproduction and Development, 39: 49-54.

67. Baird A (1994). Fibroblast growth factors: activities and significance of non-neurotrophic growth factors. Current Opinion in Neurobiology, 4: 78-86.

68. Wanaka A, Johnson EM \& Milbrandt J (1990). Localization of FGF receptor mRNA in the adult rat central nervous system by in situ hybridization. Neuron, 5 : 267-281.

69. Rifkin DB, Moscatelli D, Roghani M, Nagano Y, Quarto N, Klein S \& Bikfalvi A (1994). Studies on FGF-2: nuclear localization and function of high molecular weight forms and receptor binding in the absence of heparin. Molecular Reproduction and Development, 39: 102-104.

70. Florkiewicz RZ, Baird A \& Gonzalez AM (1991). Multiple forms of bFGF: differential nuclear and cell surface localization. Growth Factors, 4: 265-275.

71. Flott-Rahmel B, Gerdes W, Pechan PA, Brysch W, Schlingensiepen K-H \& Seifert W (1992). bFGF induces its own gene expression in astrocytic and hippocampal cell cultures. Neuroreport, 3: 1077-1080.

72. Estival $A$, Robberecht $P$, Fanjul $M$, Rouot B, Hollande E, Vaysse N \& Clemente F (1996). Cells retrovirally transfected with fibroblast growth factor-2 isoforms exhibit altered adenylate cyclase activity and Gprotein functionality. Biochemical Journal, 315: 619-624.

73. Estival A, Monzat V, Miquel K, Gaubert F, Hollande E, Korc M, Vaysse N \& Clemente F (1996). Differential regulation of fibroblast growth factor (FGF) receptor-1 mRNA and protein by two molecular forms of basic FGF. Modulation of FGFR1 mRNA stability. Journal of Biological Chemistry, 271: 5663-5670.

74. Brickman YG, Ford MD, Small DH, Bartlett PF \& Nurcombe V (1995). Heparan sulfates mediate the binding of basic fibroblast growth factor to a specific receptor on neural precursor cells. Journal of Biological Chemistry, 270: 24941-24948.
75. Murphy PR \& Knee RS (1995). Basic fibroblast growth factor binding and processing by human glioma cells. Molecular and Cellular Endocrinology, 114: 193-203.

76. Faham S, Hileman RE, Fromm JR, Linhardt RJ \& Rees DC (1996). Heparin structure and interactions with basic fibroblast growth factor. Science, 271: 1116-1120.

77. Laslett AL, McFarlane JR, Hearn MT \& Risbridger GP (1995). Requirement for heparan sulphate proteoglycans to mediate basic fibroblast growth factor (FGF-2)induced stimulation of Leydig cell steroidogenesis. Journal of Steroid Biochemistry and Molecular Biology, 54: 245-250.

78. Venkataraman G, Sasisekharan V, Herr $A B$, Ornitz DM, Waksman G, Cooney CL, Langer R \& Sasisekharan R (1996). Preferential self-association of basic fibroblast growth factor is stabilized by heparin during receptor dimerization and activation. Proceedings of the National Academy of Sciences, USA, 93: 845-850.

79. Gleizes PE, Noaillac DJ, Amalric F \& Gas $N$ (1995). Basic fibroblast growth factor (FGF-2) internalization through the heparan sulfate proteoglycans-mediated pathway: an ultrastructural approach. European Journal of Cell Biology, 66: 47-59.

80. Muthukrishnan L, Warder E \& McNeil PL (1991). Basic fibroblast growth factor is efficiently released from a cytosolic storage site through plasma membrane disruptions of endothelial cells. Journal of Cellular Physiology, 148: 1-16.

81. Ku PT \& D'Amore PA (1995). Regulation of basic fibroblast growth factor (bFGF) gene and protein expression following its release from sublethally injured endothelial cells. Journal of Cellular Biochemistry, 58: 328-343.

82. Riva MA, Donati E, Tascedda F, Zolli M \& Racagni G (1994). Short- and long-term induction of basic fibroblast growth factor gene expression in rat central nervous system following kainate injection. $\mathrm{Neu}$ roscience, 59: 55-65.

83. Riva MA, Gale K \& Mocchetti I (1992). Basic fibroblast growth factor mRNA increases in specific brain regions following convulsive seizures. Brain Research, Molecular Brain Research, 15: 311-318.

84. Iwamoto $\mathrm{Y}$, Yamaki $\mathrm{T}$, Murakami $\mathrm{N}$, Sugawa N, Yoshino E, Ueda S, Nosaka K, Nishino H \& Iwashima A (1994). Basic fibroblast growth factor messenger RNA is expressed strongly at the acute stage of cerebral contusion. Life Sciences, 55: 1651-1656. 
85. Sakaki T, Yamada K, Otsuki H, Yuguchi T, Kohmura E \& Hayakawa T (1995). Brief exposure to hypoxia induces bFGF mRNA and protein and protects rat cortical neurons from prolonged hypoxic stress. $\mathrm{Neu}$ roscience Research, 23: 289-296.

86. Andersson K, Blum M, Chen $\mathrm{Y}$, Eneroth P, Gross J, Herrera MM, Bjelke B, Bolme $P$, Diaz R, Jamison L \& Fuxe K (1995). Perinatal asphyxia increases bFGF mRNA levels and DA cell body number in the mesencephalon of rats. Neuroreport, 6: 375-378.

87. LaManna JC, Boehm KD, Mironov V, Hudetz AG, Hritz MA, Yun JK \& Harik SI (1994). Increased basic fibroblastic growth factor mRNA in the brains of rats exposed to hypobaric hypoxia. Advances in Experimental Medicine and Biology, 361: 497502 .
88. Yuguchi T, Kohmura E, Yamada K, Wanaka A, Otsuki H, Sakaguchi T, Yamashita T, Tohyama M \& Hayakawa T (1994). Messenger RNA and protein expression of basic fibroblast growth factor receptor after cortical ablation. Brain Research, Molecular Brain Research, 25: 50-56.

89. Kohmura E, Yuguchi T, Yamada K, Sakaguchi T, Wanaka A \& Hayakawa T (1995). Expression of c-fos mRNA after cortical ablation in rat brain is modulated by basic fibroblast growth factor (bFGF) and the NMDA receptor is involved in Cfos expression. Brain Research, Molecular Brain Research, 28: 117-121.

90. Giulian D, Vaca K \& Corpuz M (1993). Brain glia release factors with opposing actions upon neuronal survival. Journal of Neuroscience, 13: 29-37.

91. Muller HW, Junghans U \& Kappler J (1995). Astroglial neurotrophic and neurite-promoting factors. Pharmacology and Therapeutics, 65: 1-18.
92. Zeng BY, Jenner P \& Marsden CD (1996). Altered motor function and graft survival produced by basic fibroblast growth factor in rats with 6-OHDA lesions and fetal ventral mesencephalic grafts are associated with glial proliferation. Experimental Neurology, 139: 214-226.

93. Perkins LA \& Cain LD (1995). Basic fibroblast growth factor (bFGF) increases the survival of embryonic and postnatal basal forebrain cholinergic neurons in primary culture. International Journal of Developmental Neuroscience, 13: 51-61.

94. Rivera S, Gold SJ \& Gall CM (1994). Interleukin-1 beta increases basic fibroblast growth factor mRNA expression in adult rat brain and organotypic hippocampal cultures. Brain Research, Molecular Brain Research, 27: 12-26. 